\title{
Tuberculous constrictive pericarditis
}

\author{
Neiberg de Alcantara Lima, ${ }^{\oplus 1}$ Danielli Oliveira da Costa Lino, ${ }^{2}$ \\ Naiana Medeiros Coelho, ${ }^{3}$ Thomas Melgar ${ }^{4}$
}

${ }^{1}$ Internal Medicine, Western Michigan University Homer Stryker MD School of Medicine, Kalamazoo, Michigan, USA ${ }^{2}$ Universidade Estadual do Ceará, Fortaleza, Ceará, Brazil ${ }^{3}$ UniChristus, Fortaleza, Ceará, Brazil

${ }^{4}$ Internal Medicine/Pediatrics, Western Michigan University Homer Stryker MD School of Medicine, Kalamazoo, Michigan, USA

\section{Correspondence to}

Dr Neiberg de Alcantara Lima, neiberg.lima@med.wmich.edu

Accepted 19 June 2019

\section{DESCRIPTION}

A previously healthy 53-year-old Brazilian man presented with a 3-month history of anasarca, dyspnoea on minimal exertion, orthopnoea, paroxysmal nocturnal dyspnoea, low-grade fever and an unintentional $12 \mathrm{~kg}$ weight loss. No prior medical condition was related. No alcohol, tobacco or illicit drug use. He lived in an area that was endemic for tuberculosis, but denied sick contacts. Vital signs at admission were: blood pressure $100 / 60 \mathrm{~mm} \mathrm{Hg}$, heart rate $110 \mathrm{bpm}$, respiratory rate $26 \mathrm{bpm}$ and oxygen saturation of $98 \%$. Physical findings included jugular venous distension, pulsus paradoxus of $30 \mathrm{~mm} \mathrm{Hg}$, severe lower extremities oedema, bilateral rales and reduced lung sounds in both bases. Laboratories parameters including complete blood count, renal and hepatic function were within normal limits, brain natriuretic peptide $105 \mathrm{pg} / \mathrm{mL}$ (normal range $(\mathrm{NR})<100 \mathrm{pg} / \mathrm{mL})$, serum total protein $4.5 \mathrm{~g} / \mathrm{dL}(\mathrm{NR}=6-8 \mathrm{~g} / \mathrm{dL})$, Lactic aAcid dehydrogenase $500 \mathrm{U} / \mathrm{L}(\mathrm{NR}=140-280)$ and HIV negative. There was a clear pericardial rub. An ECG showed sinus bradycardia and left bundle brunch block. An echocardiogram revealed left ventricle ejection fraction of $64 \%$, dilated inferior vena cava, mild concentric hypertrophy, early diastolic Doppler tissue velocity at the mitral annulus (E') of $9 \mathrm{~cm} / \mathrm{sec}, \mathrm{E} / \mathrm{e}$ ' ratio of $1.3, \mathrm{E} / \mathrm{A}$ wave ratio of 1.2, hepatic vein Doppler showed reversal of forward flow during expiration and increased pericardial thickness. A chest CT is shown below (figure 1A). A diagnostic thoracocentesis was done and the analysis showed: total protein $3.5 \mathrm{~g} / \mathrm{dL}$, amylase $25 \mathrm{U} / \mathrm{L}$ (NR 20-104), lactic acid dehydrogenase $408 \mathrm{U} / \mathrm{L}$, normal adenosine deaminase, negative acid-fast bacillus, 145 white blood cells (89\% lymphocytes) and negative culture. The analysis was compatible with an exudate accordingly to Light's criteria: three out three criteria met. The patient was treated with diuretics with a minimal relief. A pericardiectomy was performed showing a thickened pericardium (figure 1B).

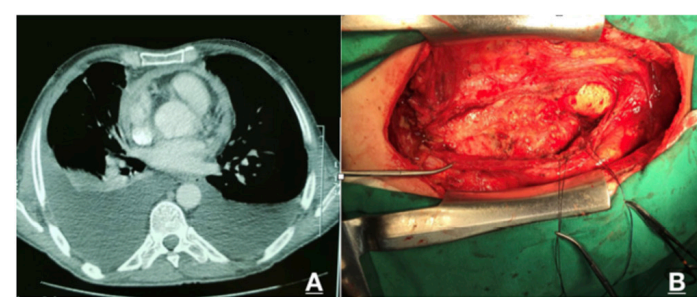

Figure 1 (A) Chest CT-bilateral pleural effusion, moderate pericardial effusion and significant pericardial thickening. (B) Surgical findings_-pericardial thickening.

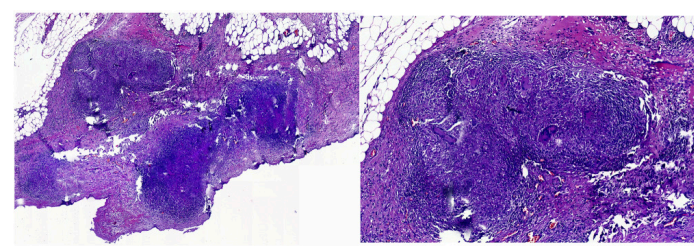

Figure 2 Photomicrograph from a biopsy specimen of the pericardium shows chronic granulomatous pericarditis with caseous necrosis suggestive of tuberculous pericarditis (H\&E)

Histopathological studies were suggestive of tuberculosis infection (figure 2). A patient was treated with rifampicin $600 \mathrm{mg} /$ day, isoniazid $300 \mathrm{mg} /$ day, pyrazinamide $2 \mathrm{~g}$ /day, ethambutol $1.6 \mathrm{~g} /$ day for 2 months followed by more 4 months of rifampicin and isoniazid in same doses. No postsurgical complication was reported. A patient has been followed monthly for one 1 year after surgery and he has been asymptomatic so far. He was diagnosed with hypertension that may explain prior left bundle branch block and concentric hypertrophy. Follow-up echocardiograms at 6 and 12 months did not show relapse.

Constrictive pericarditis is an uncommon disease that often mimics other pathologies. There is fibrous thickening of the pericardium, which impedes normal diastolic filling of the heart. This leads to a reduction in stroke volume by reducing venous return. This commonly results in symptoms of exertional dyspnoea, fatigue and can cause an elevated jugular venous pressure. ${ }^{1}$ It has been proposed that the rubbing together of the inflamed, adjacent visceral and parietal pericardial surfaces is responsible for pericardial friction rubs. However, they may be heard even when

\section{Learning points}

- Constrictive pericarditis is uncommon and sometimes mimics other pathologies and should be in the differential for patients with chronic heart failure with preserved ejection fraction.

- It is important to have a high clinical suspicion, however, echocardiogram, haemodynamic evaluation, CT and MRI are essential in the diagnosis of constrictive pericarditis.

- Tuberculosis is the most common infectious aetiology in patients with constrictive pericarditis. The treatment is pericardiectomy and pharmacological therapy with rifampin, ethambutol, isoniazid and pyrazinamide for 6 months. 
a large effusion separates the two surfaces, and once the effusion is evacuated the rub often disappears. ${ }^{2}$

Tuberculous pericarditis is found in less than 1\%-5.6\% of the constrictive pericarditis patients in North America and Europe, but can happen in more than 30\% in endemic countries. ${ }^{3}$ Progression to constrictive pericarditis, even with optimal antituberculosis therapy (without corticosteroid therapy), is reported in up to $30 \%$ of cases. ${ }^{4}$

Contributors NdAL: conception of the work, data analysis and interpretation, drafting the article, critical revision of the article and final approval of the version to be published. DOdCL: data collection. DOdCL, NMC and TM: data analysis and interpretation and final approval of the version to be published.
Funding The authors have not declared a specific grant for this research from any funding agency in the public, commercial or not-for-profit sectors.

Competing interests None declared.

Patient consent for publication Obtained.

Provenance and peer review Not commissioned; externally peer reviewed.

\section{REFERENCES}

1 Lee DZJ, Amin R, Baksi J, et al. A clinical enigma of ongoing constrictive pericarditis. Clin Med 2017:17:248-50.

2 Lange RA, Hillis LD. Acute Pericarditis. N Eng/ I Med Overseas Ed 2004;351:2195-202

3 Welch TD, Oh JK. Constrictive Pericarditis. Cardiol Clin 2017;35:539-49.

4 Chang SA. Tuberculous and Infectious Pericarditis. Cardiol Clin 2017;35:615-22.

Copyright 2019 BMJ Publishing Group. All rights reserved. For permission to reuse any of this content visit

https://www.bmj.com/company/products-services/rights-and-licensing/permissions/

BMJ Case Report Fellows may re-use this article for personal use and teaching without any further permission.

Become a Fellow of BMJ Case Reports today and you can:

- Submit as many cases as you like

- Enjoy fast sympathetic peer review and rapid publication of accepted articles

- Access all the published articles

Re-use any of the published material for personal use and teaching without further permission

Customer Service

If you have any further queries about your subscription, please contact our customer services team on +44 (0) 2071111105 or via email at support@bmj.com.

Visit casereports.bmj.com for more articles like this and to become a Fellow 